\title{
Environmental risk factors of West Nile virus infection of horses in the Senegal River basin
}

\author{
V. CHEVALIER ${ }^{1 *}$, A. DUPRESSOIR ${ }^{2}$, A. TRAN ${ }^{1}$, O. M. DIOP ${ }^{2}$, C. GOTTLAND ${ }^{1}$, \\ M. DIALLO ${ }^{2}$, E. ETTER ${ }^{1}$, M. NDIAYE ${ }^{2}$, V. GROSBOIS ${ }^{1}$, M. DIA $^{2}$, N. GAIDET ${ }^{1}$, \\ A. A. SALL ${ }^{2}$, V. SOTI ${ }^{1}$ AND M. NIANG ${ }^{2}$ \\ ${ }^{1}$ CIRAD, UR Animal et Gestion Intégrée des Risques (AGIRs), Montpellier, France \\ ${ }^{2}$ Institut Pasteur de Dakar, Unité des Arbovirus et Virus de Fièvres Hémorragiques, Dakar, Sénégal
}

(Accepted 16 January 2010; first published online 23 February 2010)

\section{SUMMARY}

In 2005, a serological study was carried out on horses in five ecologically contrasted zones of the Senegal River basin (Senegal) to assess West Nile virus (WNV) transmission and investigate underlying environmental risk factors. In each study zone, horses were randomly selected and blood samples taken. A land-cover map of the five study areas was built using two satellite ETM+ images. Blood samples were screened by ELISA for anti-WNV IgM and IgG and positive samples were confirmed by seroneutralization. Environmental data were analysed using a principal components analysis. The overall IgG seroprevalence rate was $85 \%(n=367$; $95 \%$ CI $0 \cdot 81-0 \cdot 89$ ). The proximity to sea water, flooded banks and salted mudflats were identified as protective factors. These environmental components are unfavourable to the presence of Culex mosquitoes suggesting that in Senegal, the distribution of the vector species is more limiting for WNV transmission than for the hosts' distribution.

Key words: Geographic information system, remote sensing, risk, Senegal, seroprevalence, West Nile virus.

\section{INTRODUCTION}

West Nile fever (WNF) is a mosquito-borne disease caused by a Flavivirus belonging to the Flaviviridae family. The virus is primarily transmitted from bird to bird by mosquitoes, mainly of the Culex genus. Following favourable environmental conditions, this basic cycle may be amplified leading to horse and human infections. The latter two are assumed to be dead-end hosts [1]. Due to the involvement of many bird and mosquito species and several potential transmission routes - transovarian transmission in

\footnotetext{
* Author for correspondence: Dr V. Chevalier, CIRAD, UR Animal et Gestion Intégrée des Risques (AGIRs), Montpellier, F-34398, France.

(Email: chevalier@cirad.fr)
}

Culex mosquitoes [2], bird-to-bird transmission [3], persistent infection in birds [4], and transmission by ticks [5] - WNF epidemiology is complex and multifactorial, and the influence of the environment and climatic context on West Nile virus (WNV) circulation in the USA, Europe, and Africa remains poorly understood. In Europe and Africa, WNV circulation has been recorded in very different ecosystems and climatic contexts including wetlands (Camargue, France, 2000; Senegal River valley, Senegal, 2003; Volga delta, Russia, 1999) [6-8], urban areas (Bucharest, Romania, 1996; Dakar, Senegal, 20022005) [9, 10], floodplain forest-meadow ecosystem (South Moravia, Czechland, repeated isolations of the virus and five human cases of WNF) [11] and dry areas (Var area, France; Ferlo area, Senegal) [12, 13]. 


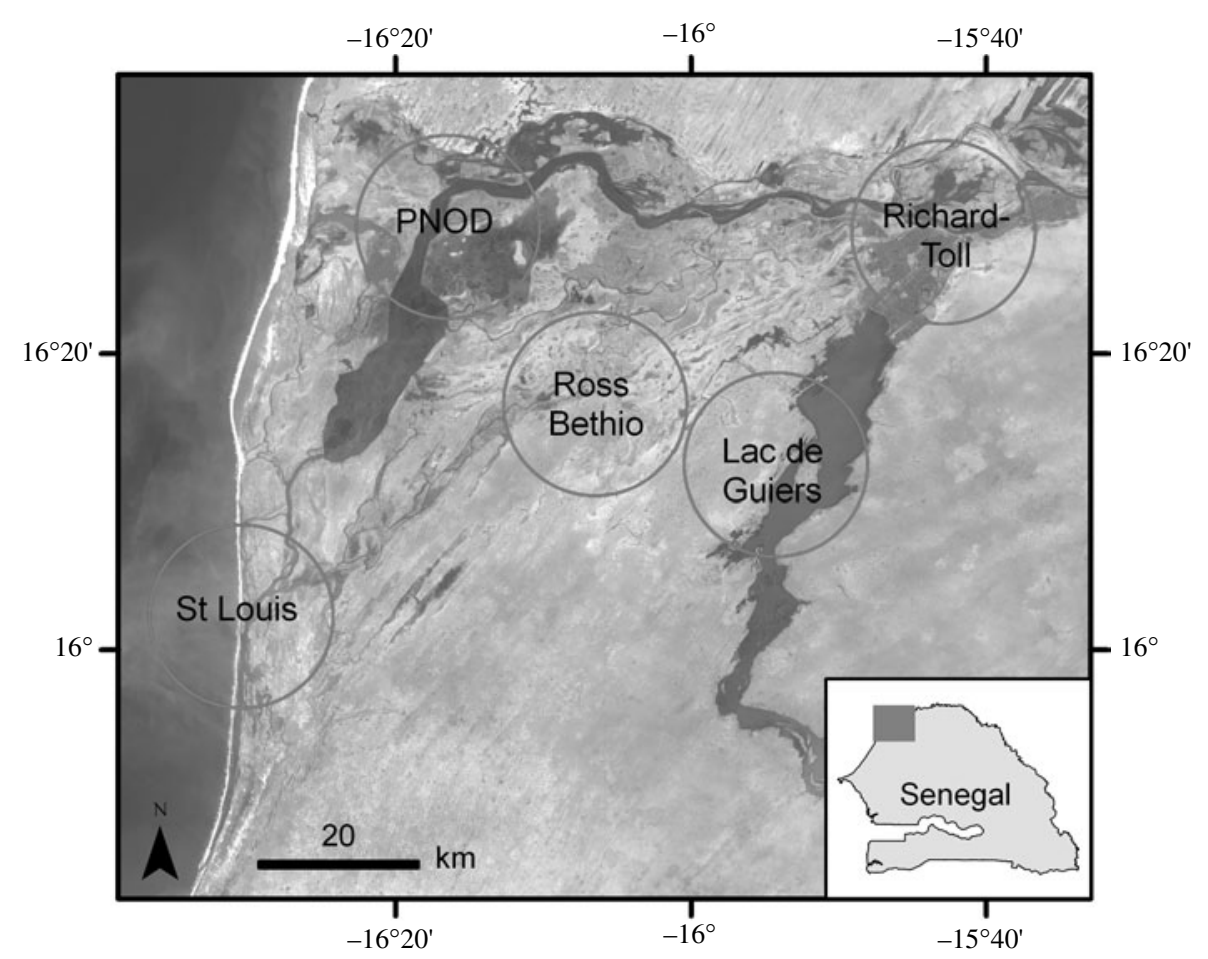

Fig. 1. Study area and location of the field study sites for the serological survey.

In Europe, the richer biodiversity of birds and the structure of the landscape were suspected to be factors favouring the circulation of WNV $[12,14,15]$. In the USA, several environmental or climatic risk factors were identified as positively correlated with higher WNV transmission depending on the study region, including farming activity and high temperatures [16], urban/suburban environment (vs. mountainous regions) [17], or the presence of vegetation in an urban context [18]. A reverse relationship between precipitation and WNF outbreaks was demonstrated in Western and Eastern USA [19]: drought was shown to be positively correlated with an increased WNV transmission level between birds and mosquitoes by concentrating both populations in smaller flooded areas [20].

The Senegal River valley, located in northern Senegal, is composed of a large delta that is known to be a major wintering area for palearctic birds. This valley also includes typical Sahelian areas, cultivated and urban zones. In this region, WNV was isolated several times from Aedes and Culex mosquitoes [21] and a serological survey showed WNV circulation in resident wild birds trapped in the wetland [7]. However, WNV transmission to horses has never been assessed in this area.

In 2005, an eco-epidemiological study was carried out in five ecologically different zones of the
Senegal River valley. The goals were to (i) assess seroprevalence of anti-WNV antibodies in horses in order to infer epidemiological implications of WNV circulation in the area and (ii) identify environmental factors potentially linked to WNV infection.

\section{METHODOLOGY}

\section{Study area}

The study area was located in northwest Senegal, lying between $15.72^{\circ}$ and $16.65^{\circ} \mathrm{N}$ and $-16.64^{\circ}$ and $-15.55^{\circ} \mathrm{E}$. This area is composed of contrasting landscapes with wet areas (swamps, rice fields) bordering the Senegal River and dry areas (herbaceous savannah, coastal dunes). The region has two climatic seasons: a rainy season from June to October that is characterized by heat, humidity and storms, and a dry season from November to May characterized by the Harmattan, a dry dusty wind that blows along the northwest coast of Africa.

Within this area, five study zones were identified. These zones were chosen as being representative samples of the different land covers in the area based on image interpretation of a Landsat Enhanced Thematic Mapper (ETM +) satellite image (4 March 2003) and field observations (Fig. 1). 
The first zone stretched from west to east around the city of St Louis. The heart of St Louis is located on a narrow island lying in the Senegal River. The river is separated from the Atlantic Ocean to the west by a narrow sandy stretch, developed into an urban area. A third part of the city lies on the eastern mainland and is almost surrounded by tidal marches. Around St Louis, the landscape is characterized by occasional acacias and dry savannah. When the river overflows into the countryside, St Louis is surrounded by flood basins. The salt water creates small ponds and stretches of mangroves where many birds come to feed.

The second zone was located in the Djoud' $j$ National Park (PNOD). The PNOD is a 16000-ha wetland located on the border between Mauritania and Senegal in the Senegal River delta. PNOD is a fragmented area composed of a large lake surrounded by streams, ponds, and backwaters. Land cover is mainly composed of acacia swamps, muddy areas, reed bed, and rice fields. The PNOD is known as a major African wintering place for palearctic birds.

The third study site was centred around RossBethio. The landscape surrounding Ross-Bethio is typically Sahelian, characterized by sand dunes and the absence of green vegetation apart from some scattered trees and shrubs during the dry season. During the rainy season the vegetation is composed of an herbaceous layer and a sparse woody plant population.

The fourth study zone was centred around RichardToll. Richard-Toll is located near the Senegal River, $80 \mathrm{~km}$ from St Louis. In addition to the city, this study site included small fields of crops such as rice and sugar cane and savannah.

The last study site was centred around Nguith village located on the banks of Lac de Guiers, known for its large population of migrating birds. The western part of this site is mainly composed of dry savannah.

\section{Epidemiological and serological data}

One market in each of the study zones was selected. Eighty horses then were randomly selected in each of the markets and blood samples taken. The ages and origins of all of the horses were recorded. Whenever possible, the GPS coordinates of where the horses lived were noted. Around each market, a $10 \mathrm{~km}$ radius buffer zone was defined. Horses that came from outside this buffer zone were discarded from the study.

Blood samples were centrifuged and stored at $4{ }^{\circ} \mathrm{C}$ before being systematically tested for WNV-specific
IgM by indirect immunocapture of $\operatorname{IgM}$, and for WNV-specific IgG by using antigen capture ELISA. Antigens were prepared from crude brain extracts of WNV-inoculated suckling mice. Serum specimen were considered positive for $\mathrm{IgG}$ when the ratio between the optical density (OD) obtained with WNV-positive antigen and WNV-negative antigen was $>0 \cdot 2$. Because of the antigenic cross-reactivity in viruses of the Flavivirus genus, and of the circulation of the Usutu virus in Senegal, an antigenically, closely related mosquito-borne member of the genus Flavivirus, validation of ELISA IgG-positive samples was necessary. All the IgG-positive sera were tested against two prototypes: WNV (B956 and Eg101) and Usutu virus (USU-SAAR) in a plaque reduction neutralization test (PRNT). All IgM-negative sera were re-tested using the same methodology. In a 96-well plate, a 1/10 dilution of each serum sample was incubated at $37^{\circ} \mathrm{C}$ for $1 \mathrm{~h}$ in a viral suspension of $20-50$ p.f.u. in $60 \mu 1$, before the addition of a porcine PS cell suspension (6.104 cells/well). After $4 \mathrm{~h}$ incubation, $120 \mu \mathrm{l} \mathrm{L}-15$ medium containing $0.6 \%$ methyl cellulose with $3 \%$ fetal bovine serum was overlaid on the well and the plates were incubated at $37{ }^{\circ} \mathrm{C}$, in $5 \% \mathrm{CO}_{2}$ for 3.5 days. The cells were stained with naphtol Blue Black solution and visualized plaques were counted. A test result was considered positive if the plaque reduction was $>90 \%$. Sera that were positive against both $\mathrm{WNV}$ and Usutu virus were titrated by twofold dilutions. Dilutions corresponding to $50 \%$ reduction of p.f.u. were regarded as the serum titres. At least a fourfold difference of WNV vs. Usutu virus titres was required to assess WNV positivity.

\section{Environmental data}

Two satellite ETM + images from the dry and wet seasons were used to provide a land-cover map of the study area. This type of sensor was chosen because the resolution (pixel size: $30 \times 30 \mathrm{~m}$ ) is adapted for the extraction of the habitats of birds, hosts of WNV, and because it made it possible to cover the entire study area. To identify the main land-cover types likely to influence the presence and/or composition of the bird population, an ecological characterization of bird habitats was first performed on the entire study area during a field survey conducted in March 2005 by a multi-disciplinary team (ornithologist, geographer, ecologist): 230 sites were georeferenced and described according to the bird population. 
Table 1. Serological prevalence of West Nile virus infection in horses of five contrasted areas of the Senegal River basin in 2005 and landscape principal component $(L P C)$ values

\begin{tabular}{|c|c|c|c|c|c|c|}
\hline \multirow[b]{2}{*}{ Study sites } & \multirow{2}{*}{$\begin{array}{l}\text { Number } \\
\text { sampled }\end{array}$} & \multirow{2}{*}{$\begin{array}{l}\text { IgG } \\
\text { sero- } \\
\text { prevalence }\end{array}$} & \multicolumn{4}{|c|}{ LPC values } \\
\hline & & & $\mathrm{PC} 1$ & $\mathrm{PC} 2$ & $\mathrm{PC} 3$ & PC4 \\
\hline Nguith & 61 & $0 \cdot 95$ & $-0 \cdot 153$ & $-0 \cdot 103$ & $-0 \cdot 187$ & $0 \cdot 047$ \\
\hline Richard-Toll & 79 & 0.92 & -0.089 & $0 \cdot 064$ & $0 \cdot 113$ & $0 \cdot 160$ \\
\hline Ross-Bethio & 68 & $0 \cdot 86$ & $-0 \cdot 168$ & $-0 \cdot 190$ & $0 \cdot 103$ & $-0 \cdot 114$ \\
\hline PNOD & 79 & $0 \cdot 82$ & -0.038 & $0 \cdot 297$ & $-0 \cdot 025$ & -0.091 \\
\hline St Louis & 80 & 0.74 & $0 \cdot 447$ & $-0 \cdot 068$ & $-0 \cdot 005$ & -0.002 \\
\hline
\end{tabular}

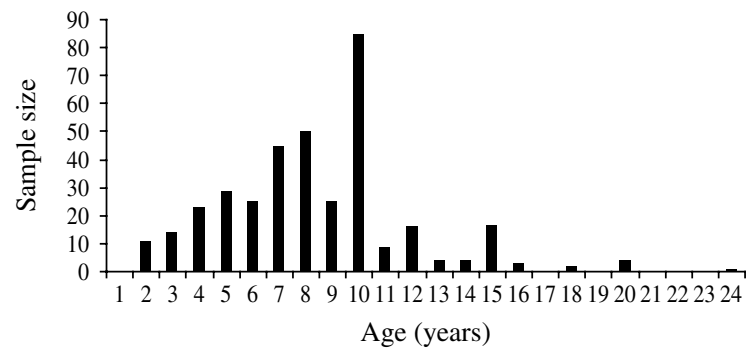

Fig. 2. Age structure of the horse samples $(n=376)$ studied to estimate the serological prevalence of West Nile virus infection in the Senegal River basin in 2005.

A supervised classification was then performed on the dry season image using these sites as a training dataset [image processing software: ERDAS Imagine (Leica Geosystems, USA)]. The second wet season image was processed to map the areas that flooded after the rainfall period. The accuracy of the classification was evaluated using a confusion matrix using a different set of training data acquired in February 2006 (190 ground control points).

From this land-cover map, the surface covered by each land-cover type was calculated for each $10 \mathrm{~km}$ radius study zone using Geographic Information System (GIS) functionalities (GIS software: ESRI ArcGIS $^{\mathrm{TM}}$, Spatial Analyst, Leica Geosystems GIS Mapping). As the surfaces occupied by the cover types within a buffer were highly correlated, a principal components analysis (PCA) was performed to synthesize the initial information on the landscape into independent factors, i.e. landscape principal component (LPC).

\section{Statistical modelling of prevalence variation}

The serological data were analysed using a generalized linear mixed model, with the individual serological status as the binomial response and age as a fixed
Table 2. Landscape classes $(n=23)$ derived from the satellite imagery and included in the classification

\begin{tabular}{|c|c|}
\hline Landscape types & Classes \\
\hline $\begin{array}{l}\text { Human and } \\
\text { cultivated areas }\end{array}$ & $\begin{array}{l}\text { Urban areas } \\
\text { Market gardens } \\
\text { Rice fields } \\
\text { Sugar-cane plantations } \\
\text { Bare soil } \\
\text { Other crops }\end{array}$ \\
\hline Arid land areas & $\begin{array}{l}\text { Dry tan } \\
\text { Seasonally flooded tan } \\
\text { Shrubland } \\
\text { Thorn-bush savannah } \\
\text { Grassland }\end{array}$ \\
\hline Wetlands & $\begin{array}{l}\text { Temporary and permanent ponds } \\
\text { Open water } \\
\text { Backwater } \\
\text { Floating aquatic vegetation } \\
\text { Marshes with Scirpus and rushes } \\
\text { Alluvial grassland }\end{array}$ \\
\hline Coastal areas & $\begin{array}{l}\text { Sea } \\
\text { Estuarine and inter-tidal mudflats } \\
\text { Herbaceous, shrubby } \\
\text { and woody coastal sand dune } \\
\text { Mangrove } \\
\text { Seasonally flooded brackish lagoons } \\
\text { Saline flats with vegetation }\end{array}$ \\
\hline
\end{tabular}

effect. Since horses were clustered by sites, site was included as a random clustering effect, which also allowed quantifying the inter-site variance.

As a first step, we investigated the effect of age on prevalence. We considered three different models. In the first model, we assumed that prevalence varied linearly as a function of age on a logit scale. In the second model, where the logit of prevalence was linearly related to the log of age, we assumed that prevalence levelled off after a certain age. In the third model, we assumed that prevalence varied in three 


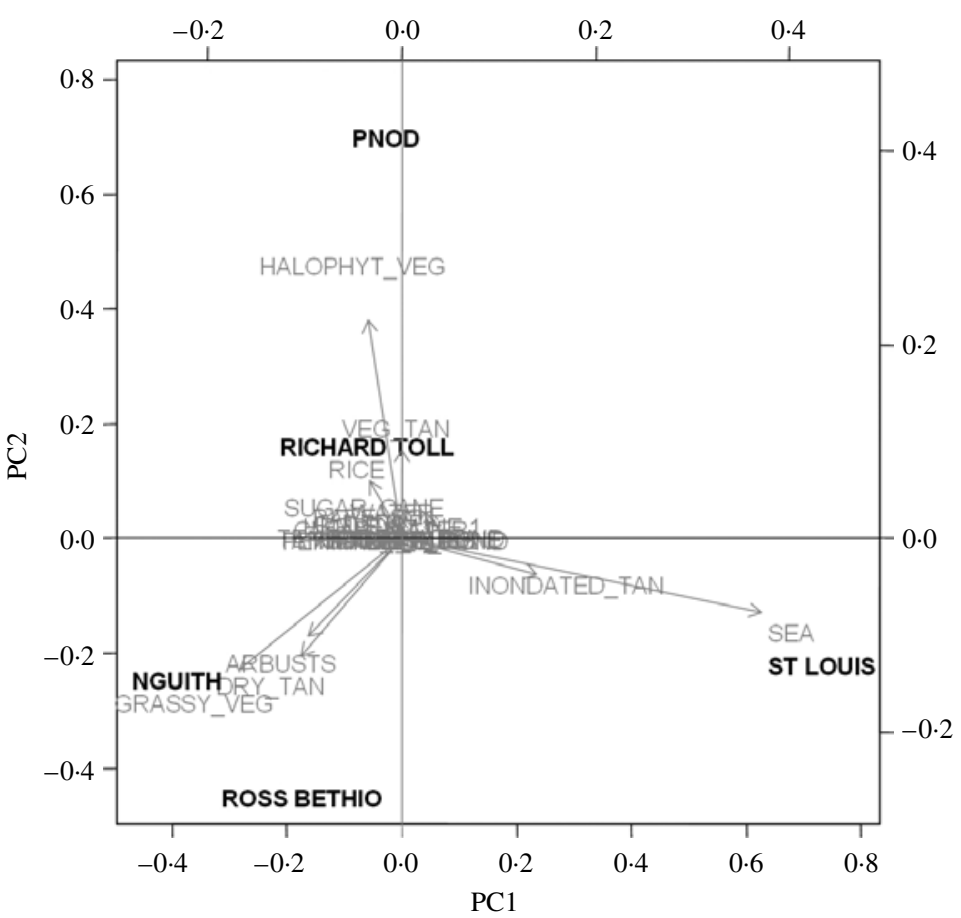

Fig. 3. Composition of the principal components (LPC1, LPC2) and projection of the five study sites on the first principal components analysis plan.

discrete age classes that were defined as follows: $[1,5)$, $[5,8)$, and $[8,+)$. In these models, variation of prevalence in sites was accounted for by a site random effect. These three alternative models for age variation in prevalence were compared using Akaike's Information Criterion (AIC).

For the second step, in order to depict age variation we included, in the selected model, the fixed effect of each of the principal landscape components which were likely to underlie the variation in prevalence in sites.

\section{RESULTS}

A total of 367 horses were included in the study, their age ranging from 2 to 24 years (Fig. 2). The overall IgG seroprevalence rate was $85 \%(95 \%$ CI $0 \cdot 81-$ $0 \cdot 89)$. The prevalence rates varied significantly from one study site to another $\left(\chi^{2}=16 \cdot 17\right.$, D.F. $=4, P=$ $0.003)$, with the highest prevalence in the Nguith site $(P=95 \%)$, followed by Richard-Toll $(P=92 \%)$, Ross-Bethio $(P=86 \%)$, and PNOD $(P=82 \%)$. The lowest prevalence rate was observed in the St Louis site $(P=74 \%)$ (Table 1$)$. No IgM antibodies were found in the samples tested.

The landscape map derived from the satellite imagery includes 23 classes that belong to four main landscape types: human and cultivated areas, arid land areas, wetlands, and coastal areas (Table 2). The overall accuracy of the classification estimated was correct $(82.54 \%)$ with 0.79 for the kappa index.

Four synthetic variables (LPC1-4) resulted from PCA. The main positive contributors to LPC1 were sea water, and flooded banks and salted mudflats (known as 'tans'). The main negative contributors were grassy vegetation and dry tans. LPC2 was mainly composed of halophyte vegetation. LPC3 was negatively composed of free water and LPC4 positively with sugar cane and negatively with never flooded, naked 'tan' (Fig. 3).

Of the candidate models depicting age variation in prevalence, the best model according to AIC was that where prevalence levelled off after a certain age (Table 3). Furthermore, the model without any age effect performed poorly compared to all of the models including an age effect (difference in AIC was always $>13 \cdot 6$ ). It thus can be concluded that age had a significant positive effect on prevalence $(P<0.001)$ (Fig. 4). The logit of prevalence varied significantly between sites [estimated standard deviation in sites: $0 \cdot 51$ (s.E. $=0 \cdot 23$ )]. Prevalence was thus linked not only with age but also with site ecological components. LPC1 explained a significant fraction of the variation in prevalence in sites $\left(P=1.5 \times 10^{-4}\right)$ suggesting 
Table 3. Selection of the best model for age variation using Akaike's Information Criterion (AIC)

\begin{tabular}{lllll}
\hline \hline Model & $\begin{array}{l}\text { No. of } \\
\text { parameters }\end{array}$ & Deviance & AIC & $\begin{array}{l}P \text { value of the } \\
\text { age effect* }\end{array}$ \\
\hline Intercept & 2 & $297 \cdot 7$ & $301 \cdot 7$ & \\
Intercept + age & 3 & 283 & 289 & $<0 \cdot 001$ \\
Intercept + clage $\dagger$ & 4 & $284 \cdot 1$ & $292 \cdot 1$ & $<0 \cdot 001$ \\
Intercept + ln(age $) \dagger$ & 3 & $278 \cdot 9$ & $284 \cdot 9$ & $<0 \cdot 001$ \\
\hline
\end{tabular}

All models include site as a random effect.

$\dagger$ Age classes.

$\ddagger \ln$ of age.

* P values were computed using likelihood ratio tests.

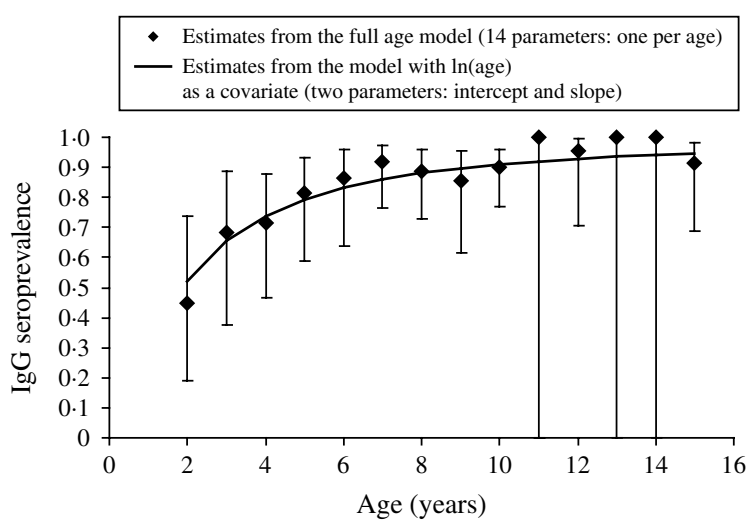

Fig. 4. Age variation in anti-West Nile virus $\operatorname{IgG}$ seroprevalence in 79 horses sampled in the PNOD study site (Senegal, 2005). Note that due to additivity of age and site in the model used to depict age variation in prevalence, patterns of age variation in the other sites are similar to that shown here for the PNOD study site.

that the components of LPC1 - sea water and tanwere protecting factors against WNV transmission (Table 4) as shown in Figure 5.

\section{DISCUSSION}

The PRNT is considered the gold standard for Flavivirus serology, and is used for validation of other tests [22]. However, even PRNT against WNV may lead to false-positive results due to cross-reactivity with other flaviviruses, especially with Usutu virus $[23,24]$. To eliminate the possibility of cross-reaction with Usutu virus, we tested positive sera against two prototypes: WNV (B956 and Eg101) and Usutu virus (USU-SAAR) using PRNT, a fourfold difference of WNV vs. Usutu titres being required to assess WNV positivity, which is a stringent interpretation criteria.
This study confirms that WNV circulation is endemic in the Senegal River basin as shown by the increase of prevalence with age.

Although the tests were performed in very different ecological contexts, the serological results were in accord with a previous study in the Ferlo area (northern Senegal) and Dakar (Senegal) in which the IgG seroprevalence rates on horses were estimated to be $78.3 \% \quad(n=120) \quad$ and $92 \% \quad(n=25)$, respectively $[10,13]$. Considering that horses live in close proximity to humans, the infection rate of horses may be regarded as a good indicator of human exposure. This very high level of transmission would justify the implementation of a surveillance system for WNV circulation in order to anticipate viral mutation that could lead to increased virulence with severe consequences on horse and human health.

IgM seroprevalence, which is an indicator of recent infection, was null: horses were sampled in July when the rainy season had just begun. In the Senegal River basin, the Culex population is somewhat reduced from November to June (B. Mondet, personal communication), starting to increase after the first rainfall events at the end of July. At the beginning of July, the transmission pressure was probably very low, explaining the absence of IgM in the samples.

The location where the horses lived was taken into account for environmental analysis because Culex mosquitoes have a crepuscular or nocturnal activity. We assumed that the location in which the horses lived was also the place where they became infected. Based on expert opinions and previously acquired field knowledge, we assumed that people walk no farther than $10 \mathrm{~km}$ from their house to reach the market. This estimation was used to define the radius of the area from which environmental data were extracted under the assumption that horses located in 
Table 4. Estimates of the parameters included in the models addressing the variation of prevalence with landscape principal components (LPC)

\begin{tabular}{|c|c|c|c|c|c|}
\hline Model & Intercept & $\begin{array}{l}\text { Coefficient } \\
\text { of } \ln (\text { age })\end{array}$ & $\begin{array}{l}\text { Coefficient of } \\
\text { PC }\end{array}$ & $\begin{array}{l}\text { Residual S.D. } \\
\text { in sites }\end{array}$ & $\begin{array}{l}P \text { value of } \\
\text { the PC effect }\end{array}$ \\
\hline Int $*+\ln ($ age $) \dagger$ & $-0.76(0.66)$ & $1 \cdot 38(0 \cdot 32)$ & n.a. & $0 \cdot 51(0 \cdot 23)$ & n.a. \\
\hline $\mathrm{Int}+\ln ($ age $)+\mathrm{LPC} 1$ & $-0.92(0.61)$ & $1 \cdot 47(0 \cdot 32)$ & $-2 \cdot 29(0 \cdot 60)$ & $0 \cdot 00003(0 \cdot 18)$ & $0 \cdot 00015$ \\
\hline Int $+\ln ($ age $)+$ LPC2 & $-0 \cdot 76(0 \cdot 70)$ & $1 \cdot 38(0 \cdot 33)$ & $-0.04(1.64)$ & $0 \cdot 51(0 \cdot 23)$ & 0.98 \\
\hline Int $+\ln ($ age $)+$ LPC 3 & $-0.76(0.66)$ & $1 \cdot 38(0 \cdot 32)$ & $-0.55(2.78)$ & $0 \cdot 51(0 \cdot 23)$ & $0 \cdot 84$ \\
\hline Int $+\ln ($ age $)+$ LPC4 & $-0 \cdot 71(0 \cdot 65)$ & $1 \cdot 35(0 \cdot 32)$ & $2 \cdot 18(2 \cdot 08)$ & $0 \cdot 48(0 \cdot 22)$ & $0 \cdot 44$ \\
\hline
\end{tabular}

Standard errors are in parentheses.

* Intercept.

$\dagger \ln$ of age.

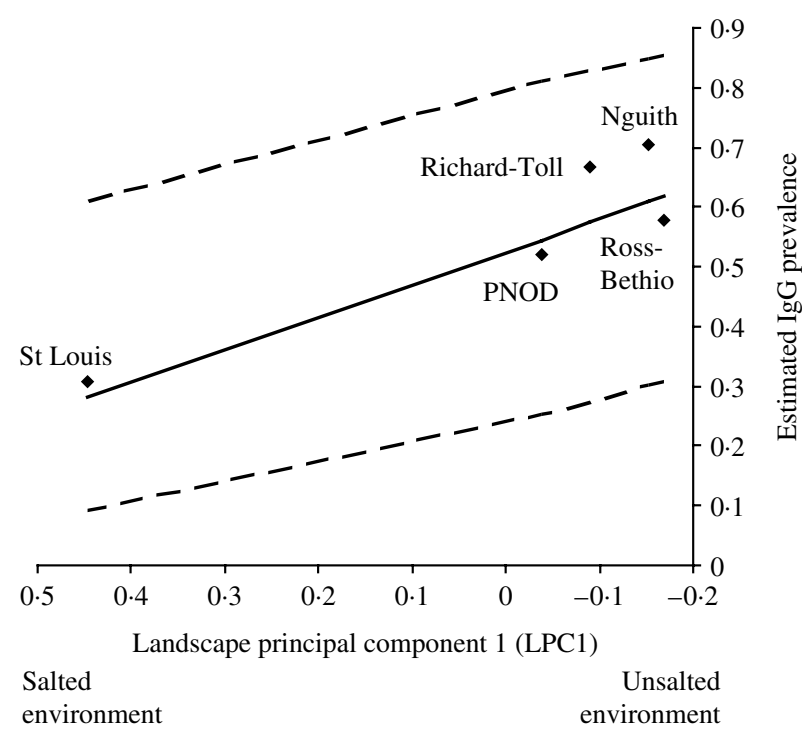

Fig. 5. Prevalence of 2-year-old horses predicted from a model with additive effects of $\ln ($ age $)$ and of site $(\bullet)$, as a function of $\mathrm{PC} 1$ values (interpreted as a gradient of saltiness of the habitat). The solid line is the regression line estimated from a model with additive effects of age and PC1. The dashed lines are the $95 \%$ confidence intervals of this regression line.

this buffer zone were equally exposed to mosquito bites.

Despite the intense WNV circulation, transmission levels varied according to the study site and landscape type, and statistical analysis suggests that sea water and tan may be protecting factors against WNV transmission in this area. This result is based on data obtained from a single sampling season. However, besides environmental characteristics (resulting from PCA), the model includes equid age, the dependent variable being age- and site-specific seroprevalence. In old animals, this variable covers both recent and past exposure to WNV infection. Furthermore, land-cover types chosen for image classification represent perennial structures. We thus believe that the environmental risk factors we obtained are valid not only for the study year but also for past years.

$C$. pipiens and $C$. modestus are the main vectors of WNV in Europe [25]. However, there is lack of knowledge on WNV mosquito vectors - identity, distribution and population dynamic, in the studied area. Several observations or studies suggest that C. poicilipes may be one of the major WNV vectors: (i) this mosquito species is one of the most abundant species in the Senegal River basin [26, 27], probably because of well developed rice plants as well as the presence of a varied community of aquatic plants and animals [28]; (ii) this species is predominantly ornithophilic [29], and (iii) WNV was isolated from this mosquito species in Senegal (CRORA database http://www.pasteur.fr/recherche/banques/CRORA). This species was also mentioned as a WNV carrier in Egypt [30]. The biology of Culex mosquitoes, may explain the results of the environmental analysis. It is known that Culex mosquitoes prefer water contaminated with organic matter or slightly brackish, rice fields, irrigation canals, and semi-permanent marshes for the development of larvae [31]. Urban and cultivated areas are thus favourable habitats for this mosquito species. The same may not be said for ' $\tan$ ', which are very dry and sometimes salty surfaces where only acacias can grow. This land-cover type is thus particularly unfavourable to these mosquitoes, as is salty water, in which Culex larvae can not survive. Moreover, the wind blowing in from the sea may explain why WNV transmission is lower in St Louis than in the other selected sites. As the two identified protecting factors against WNV transmission are unfavourable factors for Culex mosquitoes, our results suggest that in Senegal, the distribution of the vector 
species is more limiting for WNV transmission than for the hosts' distribution.

In Europe, many outbreaks occurred in salty environments or wetlands located along the sea coast, suggesting that observations performed in Africa cannot be extrapolated to Europe. Similarly, the highest seroprevalence rate was detected in Nguith, and not as expected in PNOD, because of its high level of landscape fragmentation [32]. West African and European WNV epidemiological systems should be distinguished from each other; the identification through an environmental approach of factors favouring WNV circulation in Africa consequently cannot be transposed to Europe. Long-term longitudinal studies in sentinel domestic and wild birds as well as small-scale environmental studies may help identify these factors.

Finally, the Senegal River basin is known as a major wintering area for European migrating birds. As previously suggested $[33,34]$ this could transport the virus to Europe and contribute to the initiation of WNV circulation in temperate regions. Further investigative studies are needed on the role of migrating birds in the transport and emergence of WNV in Europe and on the factors involved in this process in order to build a prediction model, and test the effect of climate and meteorological events, migration patterns, local conditions, and the role of nestling birds in cycle amplification.

\section{ACKNOWLEDGEMENTS}

This study was partially funded by the CORUS project (French Ministry of Foreign Affairs) and GOCE-2003-010284 EDEN grants. This publication is catalogued by the EDEN Steering Committee as EDEN00xx (www.edenfp6project.net). The contents of this publication are the sole responsibility of the authors and do not necessarily reflect the views of the European Commission.

\section{DECLARATION OF INTEREST}

None.

\section{REFERENCES}

1. Dauphin G, et al. West Nile: worldwide current situation in animals and humans. Comparative Immunology, Microbiology and Infectious Diseases 2004; 27 : 343-355.
2. Dohm DJ, Sardelis MR, Turell MJ. Experimental vertical transmission of West Nile virus by Culex pipiens (Diptera: Culicidae). Journal of Medical Entomology 2002; 39: 640-644.

3. Hartemink NA, et al. Importance of bird-to-bird transmission for the establishment of West Nile virus. Vector Borne Zoonotic Diseases 2007; 7 : 575-584.

4. Komar N, et al. Experimental infection of North American birds with the New York 1999 strain of West Nile virus. Emerging Infectious Diseases 2003; 9: 311-322.

5. Anderson J, et al. Transstadial transfer of West Nile virus by three species of ixodid ticks (Acari: Ixodidae). Journal of Medical Entomology 2003; 40 : 528-533.

6. Durand B, et al. West Nile Virus outbreak in horses, Southern France, 2000: results of a serosurvey. Emerging Infectious Diseases 2002; 8: 777-782.

7. Chevalier V, et al. Predicting West Nile virus seroprevalence in wild birds in Senegal. Vector Borne Zoonotic Diseases 2009; 6: 589-596.

8. Lvov DK, et al. Isolation of two strains of West Nile virus during an outbreak in southern Russia, 1999. Emerging Infectious Diseases 2000; 6: 373-376.

9. Savage HM, et al. Entomologic and avian investigations of an epidemic of West Nile fever in Romania in 1996, with serologic and molecular characterization of a virus isolate from mosquitoes [published Erratum appears in Am. J. Trop. Med. Hyg. 2000; 62: 162]. American Journal of Tropical Medicine \& Hygiene 1999; 61: 600-611.

10. Cabre O, et al. West Nile virus infection: serological investigation among horses in France and in Africa. Medecine Tropicale 2005; 65: 439-443.

11. Hubálek $\mathbf{Z}$, et al. West Nile virus investigations in South Moravia, Czechland. Viral Immunology 2000; 13: 427-433.

12. Durand B, et al. Serosurvey for West Nile viruses in horses in southern France. Veterinary Record 2005; 157: 711-713.

13. Chevalier V, et al. Serological assessment of West Nile fever virus activity in the pastoral system of Ferlo (Senegal). Annals of the New York Academy of Science 2006; 1081: 216-225.

14. Pradier S, Leblond A, Durand B. Biodiversity landscape metrics and West Nile virus circulation in southern France. Vector Borne and Zoonotic Diseases 2008; 8: 253-263.

15. Ezenwa VO, et al. Avian diversity and West Nile virus: testing associations between biodiversity and infectious disease risk. Proceedings of the Royal Society of London, Series B 2006; 273: 109-117.

16. Miramontes R, et al. Is agricultural activity linked to the incidence of human West Nile virus? American Journal of Preventive Medicine 2006; 30: 160-163.

17. Gibbs SEJ, et al. Factors affecting the geographic distribution of West Nile virus in Georgia, USA: 2002-2004. Vector Borne Zoonotic Diseases 2006; 6: 73-82.

18. Ruiz MO, et al. Environmental and social determinants of human risk during a West Nile virus outbreak in the 
greater Chicago area, 2002. International Journal of Health Geographics 2004; 3: 8-19.

19. Landesman WJ, et al. Inter-annual associations between precipitation and human incidence of West Nile virus in the United States. Vector Borne Zoonotic Diseases 2007; 7 : 337-343.

20. Shaman J, Day JF, Stieglitz M. Drought induced amplification and epidemic transmission of West Nile virus in southern Florida. Journal of Medical Entomology 2005; 42: 134-141.

21. Traore-Lamizana M, et al. Isolations of West Nile and Bagaza viruses from mosquitoes (Diptera: Culicidae) in central Senegal (Ferlo). Journal of Medical Entomology 1994; 31 : 934-938.

22. Hubalek Z, et al. Serological survey of birds for West Nile Flavivirus in southern Moravia (Czech Republc). Vector Borne Zoonotic Diseases 2008; 8: 1-8.

23. Niedrig M, et al. Comparison of ELISA and immunoassays for measurement of IgM and IgG antibody to West Nile virus in human sera against seroneutralization. Journal of Virological Methods 2007; 139: 103-105.

24. Crill WD, Chang GJJ. Localization and characterization of Flavivirus envelop glycoprotein cross-reactive epitops. Journal of Virology 2004; 78: 13975-13986.

25. Hubalek Z. European experience with the West Nile virus ecology and epidemiology: could it be relevant for the new world? Viral Immunology 2000; 13: 415-426.

26. Diallo M, et al. Mosquito vectors of the 1998-1999 outbreak of Rift Valley Fever and other arboviruses
(Bagaza, Sanar, Wesselsbron and West Nile) in Mauritania and Senegal. Medical and Veterinary Entomology 2005; 19: 119-126.

27. Fontenille D, et al. New vectors of Rift Valley fever in West Africa. Emerging Infectious Diseases 1998; 4: 289-293.

28. Snow WF. Mosquito production and species succession from a area of irrigated rice fields in The Gambia, West Africa. Journal of Tropical Medicine \& Hygiene 1983; 86: $237-245$.

29. Gordon SW, et al. Feeding patterns of mosquitoes collected in the Senegal river basin. Journal of the American Mosquito Control Association 1991; 7: 424-432.

30. Orshan L, et al. Mosquito vectors of West Nile fever in Israel. Journal of Medical Entomology 2008; 45: 939-947.

31. Beaty BJ, Marquardt WC. The Biology of Disease Vectors. Niwot: University Press of Colorado, 1996, 632 pp.

32. Pradier S, Leblond A, Durand B. Landcover, landscape structure, and West Nile virus circulation in France. Vector Borne Zoonotic Diseases 2008; 8: 253-263.

33. Zeller H, Schuffenecker I. West Nile virus : an overview of its spread in Europe and the Mediterranean Basin in contrast to its spread in the Americas. European Journal of Clinical Microbiology and Infectious Diseases 2004; 23: $147-156$.

34. Malkinson M, Banet C. The role of birds in the ecology of West Nile virus in Europe and Africa. Current Topics in Microbiology and Immunology 2002; 267: 309-322. 